\title{
4 Patriarchy in Borderland Tribes: The Galo House Space as a Gendered Construct
}

Jombi Bagra, Assistant Professor, Department of English, Government College

Doimukh, Arunachal Pradesh.India.email:jombi22@yahoo.com

\begin{abstract}
In patriarchy, a family is the primary social institution for reinforcement of patriarchal ideology. A child learns orally, and through observation and practice, he/she learns the gender relations in the family. The living space of the family itself reflects various dimensions of patriarchal culture. The present paper is an attempt to examine the nature of the patriarchal set up with reference to Galo house space, which also a learning space for patriarchal values in the family.

Galo is a patriarchal tribe in Arunachal Pradesh. They mainly live in Aalo, Basar, Pasightat, Daporijo, Namsai, Itanagar etc. though their concentration is in West Siang and Lepa Rada districts. Socially they are divided into three groups- Pugo, Lare and Lodu Karka. However, the house space provides an identical gendered structure and function. The present study describes the structure and function of house space in a gendered perspective.
\end{abstract}

Keywords: Patriarchy, Galo, Borderland Tribes, Arunachal Pradesh

\section{Introduction}

It is said that when a child is born, he or she is born in a culture. The cultural space is an abstract conception. In other words, a child is born to a family which is a functional manifestation of the cultural space of a community. Thus, it is the family that socialises and encultures a child the various aspects of cultural life. It is but natural that the structure and function of the family and the house in which the family is accommodated embody the cultural space. In this paper, an attempt is made to examine the cultural space of the structural and functional aspect of the dwelling house of the Galo tribe of Arunachal Pradesh. 


\section{(C) Jombi Bagra}

The Galos is one of the major tribes inhabiting West Siang, Lepa Rada, East Siang and the eastern fringe of Upper Subansiri district of Arunachal Pradesh. They are divided into three groups- Pugo, Lare and Lodu Karka on the basis of their linguistic variation (Basar 2007:195).

Traditionally they are jhum cultivators but in present time wet rice cultivation and terrace cultivation are equally popular. Hunting and fishing are also the earliest occupations for food gathering but with the domestication of animals, hunting and fishing has gradually changed from means of livelihood into a form of entertainment and pastime. In addition, they collect vegetables, fruits, edible roots, honey etc from the forest. They practice Donyi-Polo as their religion. They settle intra as well as inter-community disputes through the system of Keba (village council). Keba is a male organization. Women are not allowed in decision making. The Galo society is patriarchal, patrilineal and patrilocal. The tribe is organised into sub-tribe, phratry, clan, sub-clan, lineage and family.

Family, nam-rumtum is the smallest social unit. Family type varies from extended family to the nuclear family. Traditionally the family was extended later joint families came up and now the nuclear family is an emerging trend. All these three types exist in the tribe. Father is the head of the family and all the family members follow his instruction. In marriage, they follow tribe endogamy and clan exogamy. The general trend of marriage is monogamy but polygyny is also practiced.

Most of the Galo villages are situated on the hill spurs and houses (name) are generally built on a platform with varied size. Each house in a village has a Nasu (granary). They are built in the outskirts of the village as a preventive measure to protect them from fire accident as valuable traditional items are kept in the Nasu along with grains. The houses are raised on struts of bamboo or wood at a height of four to twelve feet from the ground. The house consists of a big hall. The hall serves the purpose of the bedroom, living room, dining room, kitchen. (Srivastava 2010:14)

\section{Patriarchy among Galos}

Patriarchy is a feature common to all the tribes of the present state of Arunachal Pradesh. This basically determines the gender relations and is the cause of the existence of various discriminatory practices against women. These practices may have had some functional attributes, but over the years the continuity of these practices has led to the display of male superiority behind the veil of customs and 


\section{(C) Jombi Bagra}

traditions. (Behera and Basar 2008:9) In fact, males rule females by the right of birth and even if the male child is not the firstborn in the family, he is automatically considered the head of the household. Further, the preference of a male child also sanctions a man to go for another marriage if the woman does not bear a male child. From the early childhood, sons generally stay in the company of father and other male members and learns to hunt and trap. They participate in community hunting, fishing, trapping, collecting materials for construction of the house, fence etc. On the other hand, daughters by staying in mother's company and other female members learn to weave and other household chores such as fetching water and firewood, grinding and husking grains, cooking and serving, pounding rice, brewing rice beer, collecting wild vegetables, cleaning and washing utensils and clothes, nursing and looking after children and younger siblings etc. (Bagra 2009:11)

The Galos of Arunachal Pradesh is a patriarchal tribe. Therefore, Galo man and woman has to learn patriarchal values to become an eligible member of Galo culture. In this regard, it is to be mentioned that the first lesson along the gender line begins from the dwelling house. Before discussing cultural space relating to the structural and functional aspect of the dwelling house, an overview of Galo as a patriarchal is presented. This overview is made with respect to the phenomenon of property and inheritance.

\section{Property and Inheritance}

Among the Galos, the ownership of property and inheritance are along the male line. In principle, women do not have ownership rights of immovable property like land, house etc. and other properties in the form of livestock. But it needs some qualification. A woman can rear a pig, own it and sell it as long as she is a member of the family. But when she leaves the family, she cannot claim ownership over it. The family properties are inherited by son/sons. However, daughters share some movable properties like Tadok, Hurgen (beads, brass ornaments) upon their marriage. Even when a man does not have a male child; the ownership right goes to the sons of a brother(s). In case there is no son in the family to inherit the property, it is passed on to the son(s) of paternal cousin(s). Therefore, denial of inheritance rights amounts to the denial of ownership rights. (Bagra 2009:9)

However, inheritance in relation to women has a broader meaning. A woman is usually compensated in terms of bride price when she marries and therefore, there is an inherent belief that women are equivalent 


\section{(C) Jombi Bagra}

to commodities which can be purchased. Usually, a woman is considered as a property. Being a property, she has the potentiality of being inherited.

\section{House Space - A Gendered Construct}

A Galo house is a rectangular space and has an interior and an exterior portion. The exterior of the house i.e. Koda (verandas) lie along with the breadth of the house. Front of the house that makes the Nyilo Koda (male veranda) usually lies towards east. Nyilo Koda is mainly used by menfolk as a sit out. Earlier Nyilo Koda had a hearth used for cooking meat and other items by the male members during rituals and festivals. The entry of female members to Nyilo Koda during menstruation is prohibited. Back portion of the house is called Nyim Koda (female veranda). Nyim Koda (female veranda) lies towards Pimme area. It is used by female members to sit out and other activities such as winnowing, weaving etc. Space is also used for cleaning utensils, water pots and for storing firewood for immediate use.

As has been mentioned above, the Galos build their houses on a platform and the height of which varies from house to house depending on the slope of the ground (Basar 2006:109). It is interesting to note that they use two Kobas ${ }^{[1]}$ (ladders) separately for male and female respectively to reach the house. Nyilo Koba (male ladder) is connected to the male veranda and Nyim Koba (female ladder) to the female veranda. Female members are prohibited from using Nyilo Koba after puberty whereas Nyim Koba which is meant for the female is used by both male and female. Both Nyilo Koda and Nyim Koda are connected with two balconies called Inyik along the length of the house. One can move from male veranda to female veranda and vice versa through the Inyik. The interior of the house, i.e Namra is a big hall and is divided into Pinte and Pimme with a Miram (hearth) in each portion. One can enter Pinte and Pimme through two separate Rabgo (doors) i.e. Nyilo Rabgo (male door) and Nyime Rabgo (female door). 'It is said that pinte is for derne pane (unpolluted) and pimme for dermana (polluted)' (Basar 2006:112). Nyilo rabgo is meant for male members and females are generally prohibited to use this door especially during menstruation. Pinte area is more spacious than Pimme. Pinte consists of Bago, Nyode, Udu and Nyosi. Bago lies toward Nyilo Koda and is entered through nyilo rabgo constructed on the wall separating Nyilo Koda and Bago.

11 These days the distinction is not made in some houses converted to Christianity or influenced by modernity. 


\section{(C) Jombi Bagra}

It is believed to be the abode of Bago Uyi. He is the deity whose blessings make a man a good hunter. The jaws and skulls of wild animals, bow and arrows and gun are hung on the wall of the Bago. This is done to mark the bravery of the male members of the house, especially those who have hunted down these wild animals. Bago is a place exclusively used by male members. women are prohibited to sit or use the Bago after puberty. If by mistake, a girl or a woman uses the Bago, the Bago Uyi is insulted and this can result in the various ailment of the woman (Basar 2006:113).

Towards the left side of Bago lies Nyode. It is believed to be the dwelling place of Hitum-jore, the creator. Nyode is generally occupied by the master and mistress of the house. Rituals associated with ayi-agam (blessings for good fortune and prosperity) is performed in the Nyode. Dosi-ginsi (ceremonial basket) used by women to collect paddy from nasu (granary) and ayi-agam during Mopin (annual festival of harvest and fertility) is kept in the Nyode. New born is brought to Nyode for a ritual called Layap after five (or six) days of its birth when its umbilical cord stump falls off. It is performed so that Hitum-jore identifies the baby and take it under her protection. The ritual symbolizes the acceptance of baby as a member of the household. Layap is also performed for new bride so that Hitum-jore recognises her as the member of the family. (Basar 2006:114).

$U d u$ area is meant for the guests and it lies to the right of the Bago. Towards the opposite of Bago lies Nyosi that divides Pinte from Pimme. Nyosi is usually used by womenfolk during preparation of food. Pimme area has a separate door called nyime rabgo (female door). It is used for entry and exit of women. However, there is no restriction for male members. The Galo women confine themselves to pimme area of the house during menstruation, miscarriage and after delivery. They are prohibited from entering bago, nyode and nyilo koda during this time.

They cook food in Miram (hearth) in Pimme area. They are deemed to be sacrilegious during these periods. A separate set of utensils are used during this phase which are not shared by others. The utensils or sitting plank (dumpa) used by the menstruating woman are segregated and kept away from items of normal use. This is done to prevent other members from using it mistakenly or brought to the Pinte unknowingly. Preparation of opo (rice beer), the job of female members is done in Pimme. 


\section{(C) Jombi Bagra}

\section{Basis of Gender Construct and Implication}

Like any other system of belief, the idea of purity and pollution regulate the behaviour and attitude towards life. The idea of purity and pollution are further strengthened through the observance of various taboos. In fact, pollution is the weapon which the man wields to keep the woman under control and subjugated. The pollution attributed to a woman not only determines her status but also affect male masculinity. That is why Galos believe in preserving the masculinity which makes them expert in some areas such as hunting, oratory, decision-making capacity etc. Restrictions are put on men to abstain from physical intimacy on certain occasions. It is believed that a man must avoid the company of woman during the period of her menstruation. A hunter is prohibited from physical intimacy night before the hunting expedition. Any violation will result in the loss of manly qualities like hunting, fishing, climbing trees, diving in the river, mental development, strength and power etc. If he does not abstain himself from the company of woman during such period, it is believed that female-like quality will be transferred to him.

A hunter is prohibited to participate in hunting expeditions particularly in community hunting if his wife is menstruating. The presence of a menstruating woman in the house is believed to bring bad luck for the hunter. It is not the mere company but the very presence of a menstruating woman in the house is considered to be polluting and thereby reducing the manly quality required at the time of hunting. However, the restriction is imposed depending on the strength, stamina, etc. to be acquired in an activity. That is why, if the husband of a menstruating woman has to participate in hunting, he has to spend the night in someone else's house or in the dere (community hall). Such conceptions have transfused into the non-traditional dimensions of modern life. For example, in the present time before a football match, the players of a village usually stay in the dere till the end of the tournament to avoid pollution and hence the chance of losing.

Along with such ideas of purity and pollution, the biological factor is socially and culturally constructed to assign a lower status to a woman. A woman is considered a polluting agent particularly due to the biological occurrence i.e. menstruation. This period is considered the period of pollution and there are many restrictions imposed on women. A menstruating woman is not allowed to touch or step over the hunting and fishing instruments. She can engage in household work like brewing the beer, cooking the meals and going to jhum fields etc. It is to be mentioned that female as such is not polluting/ed on many 
The Researchers' - Volume VI, Issue I, 10 March-2020

International Research Journal (Double-blind peer-reviewed)

Date of Acceptance : 12 November 2019
ISSN : 2455-1503

Impact Factor $\mathbf{-} 3.635$

DOI - 10.21276/tr.2020.6.1.AN4

\section{(C) Jombi Bagra}

occasions. It is only during the fertility period i.e. starting from puberty to menopause that women are considered polluted. So, they observe many restrictions during menstruation and confine themselves in that portion of the house meant for women. Women during the fertility period are strictly prohibited to use the male ladder. But woman before puberty and after menopause do not follow such restrictions.

\section{Conclusion}

In a community, culture space pervades both material and non-material aspects of life. Therefore, the dwelling place is not an exception. The dwelling place is a microcosm of cultural beliefs among the Galos. Being a patriarchal society, the core of culture is a gender manifestation. This aspect is very much reflected in the house which is divided into different compartment along the gender line. Not only the divisions of the house facilitate gender-related practices but also become an agent of socialization of children about the patriarchal practices and values.

\section{Reference}

Bagra, Jombi.(2010) Interpretation of Woman in Patriarchy:A case study of Galo. Unpublished M. Phil dessertation, Arunachal Institute of Tribal Studies, Rajiv Gandhi University, Itanagar

Basar, Jumyir (2006). "Galo House as a Cultural Space”, Resarun, Journal of the Directorate of Research. Vol.32, Government of Arunachal Pradesh, Itanagar, pp.105-118

Basar, Jumyir (2007). "Rituals and Taboos in Galo Marriage" in T. Mibang \& MC Behera (eds.) Marriage in Tribal Societies: Cultural Dynamics and Social Realities, Bookwell, New Delhi, pp195-212

Behera, M.C. \& Jumyir Basar (2008), Embeddedness of Violence in Inequality: Understanding Violence Against Women in Patriarchal Tribal Culture with Arunachal Pradesh as Case Study, Paper submitted in the $29^{\text {th }}$ NIEHA session in Dibrugarh University.

Loyi Jommi (2001). Aspects of the Social Institution of the Galos: A case Study of Along Circle in West Siang District, Arunachal Pradesh, Unpublished M.Phil. Dissertation, Department of Tribal Studies, Arunachal University 
The Researchers' - Volume VI, Issue I, 10 March-2020

International Research Journal (Double-blind peer-reviewed)

Date of Acceptance : 12 November 2019
ISSN : 2455-1503

Impact Factor - 3.635

DOI - 10.21276/tr.2020.6.1.AN4

(C) Jombi Bagra

Norbu, T (1997). “Gallong”. In B. B. Pandey (ed.) Status of Women in Tribal Society: Arunachal

Pradesh, Directorate of Research, Government of Arunachal Pradesh, Itanagar, Himalayan Publishers, pp.122-132.

Nyori, T. (1993), History and Culture of the Adis, Omson Publications, New Delhi.

Srivastava, L.R.N(1988), The Gallongs, Director of Research of Research, Itanagar, Government of Arunachal Pradesh, 791111 